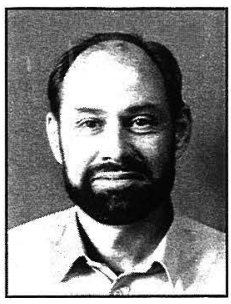

\title{
DIVERgING PATHS ? EMPLOYMENT RELATIONS IN NEW ZEALAND AND DENMARK IN THE 1990'S
}

\author{
Erling Rasmussen and Jens Lind \\ University of Auckland \\ and University of Aalborg
}

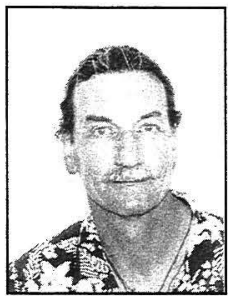

This paper discusses two interlinked topics: the shifts in the employment relations system and the role of unions in the two countries. An initial impression is that there is a growing divergence between the employment relations systems in the two countries over the last fifteen years. The implementation of free-market policies in New Zealand can be contrasted with a more mixed philosophical basis of the Danish reforms. However, the paper tries to demonstrate through an analysis of key employment relations regulations that a more complex pattern of divergence and convergence exists.

When it comes to the role of unions, the paper presents a clear-cut divergence pattern. This raises two querstions. Why have the Danish unions avoided the widespread decline in unionism? Why has the decline in union presence been so marked in New Zealand, and will the unions rebound from this decline?

Keywords: employment relations, bargaining, unions, Denmark

Both New Zealand and Denmark have a small population, an industry structure influenced by the traditional strength of agriculture and the predominance of small organisations. Historically, they have had a well-developed welfare system and an extensive public sector. The strong role of the state has shaped employment relations in both countries.

This paper discusses two interlinked topics: the shifts in the employment relations system and in the role of unions in the 1990's. An initial impression is that there is a growing divergence between the employment relations systems in the two countries. The implementation of free-market policies in New Zealand can be contrasted with a more mixed philosophical basis of the Danish reforms. However, the paper tries to demonstrate through an analysis of employment relations regulations that a more complex pattern of divergence and convergence exists.
When it comes to the role of the unions, the paper presents a clear-cut divergence pattern. This raises two questions. Why has the decline in union presence been so strong in New Zealand and why have the Danish unions avoided the widespread decline in unionism? These questions are analysed within a theoretical framework proposed by Visser (1991).

The paper is based on results from our long-term comparative research project which has focussed on the following topics: the role of the state, the role of collective action and unions, bargaining trends, employee choice and voice, changes in working time and work patterns, employment and unemployment policies. As this paper is presented to a New Zealand audience, it is assumed that the reader will be unfamiliar with the Danish employment relations system. Thus, the paper will put more emphasis on explaining characteristics and trends of the Danish system. ${ }^{1}$

\section{Table 1. Bargaining principles - New Zealand \& Denmark in the 1990's}

\begin{tabular}{l|l}
\hline New Zealand & Denmark \\
\hline - Non-prescriptive & - Non-prescriptive \\
- Individual focus & - Collective focus \\
- Sanctity of contract & - Sanctity of contract \\
- Disputes of interest \& rights & - Disputes of interest \& rights \\
- Recognition versus bargaining rights & - Neither recognition nor bargaining rights \\
- Minimum conditions & - Minimum conditions \\
\hline
\end{tabular}




\section{Employment relations systems}

In the following, some of the key characteristics of the two countries' bargaining frameworks are presented in Table 1. The table provides a framework for a discussion of patterns of convergence and divergence. A key argument of this paper is that the transformation of New Zealand employment relations - from the previous conciliation and arbitration system to a deregulated system under the Employment Contracts Act (ECA) (Rasmussen \& Boxall, 1995: 79-81) - has moved it closer to the Danish system. Table 1 tends to exaggerate the similarities. However, both similarities and differences will be explored in more detail in the following discussion of the key bargaining principles.

\section{The bargaining scenario in New Zealand}

The bargaining scenario under the ECA can be summarised in the following way.

The ECA has been called non-prescriptive or enabling legislation (Rasmussen \& Lamm, 1999). This was clearly an intentional move to allow employers and employees to choose their own bargaining arrangements and outcomes (Birch, 1991; Deeks et al, 1994: 85). The shift to a totally different employment relations system also introduced several new, undefined terms, which has subsequently allowed legal precedent to become a key feature of establishing new bargaining rules (Anderson, 1997).

The individual focus of the ECA is pronounced in its treatment of collective bargaining and unions (see below). In particular, the restrictions on multi-employer bargaining with direct and secondary strike action in seeking a multiemployer collective employment contract being deemed unlawful - have had negative implications for collective bargaining. These restrictions have been heavily criticised by the $\mathrm{ILO}$ as violating New Zealand's international obligations (Haworth \& Hughes, 1995; Novitz, 1996).

The individual focus goes further, however, than the obvious restrictions of collective bargaining. The individual employer or employee is the key actor under the ECA, with other actors being reduced to secondary, agent status. This is obvious in terms of personal grievances and it is also illustrated by the preference for individual, often written, authorisation of union negotiators. As Dannin (1997) points out, this is a usual practice amongst OECD countries. In essence, the understanding of the Act's two key concepts of 'Freedom of Association' and 'Freedom of Choice' is based on a individualistic perspective (Rasmussen et al, 1996).

The sanctity of contract principle is - together with the principles of freedom of association and freedom of choice one of the key underlying principles of the ECA. The sanctity of contract has been further strengthened by legal precedent; in particular through several Court of Appeal decisions in 1998 (Rasmussen \& Lamm, 1999: 53-58). The notion of sanctity of contract was a prominent underlying principle prior to the ECA, as one would expect of the legalistic conciliation and arbitration system (Deeks et al, 1994).
Nevertheless, this principle was severely challenged under the development and debate of the ECA where Treasury officials suggested opting-out possibilities similar to 'employment-at-will' contracts (Walsh \& Ryan 1993: 21-22). The sanctity of contract notion was endorsed by Parliament during the 1991 policy debate. It has subsequently become more than just an abstract public policy principle: it is a key principle in both collective and individual bargaining and it has become part of standard awareness amongst employers and employees. ${ }^{2}$

The important distinction between disputes of interest and disputes of rights has been part of New Zealand bargaining since its inclusion in the Industrial Relations Act 1973. This inclusion was inspired by American practices. It was an important way of containing disputes over contract interpretation and it interacted, therefore, with the contract of sanctity principle. While there is no explicit mentioning of the distinction between disputes of interest and disputes of rights in the ECA, the distinction is clearly contained in the dispute procedures stipulated by the Act (Rasmussen \& Lamm, 1999).

The recognition versus bargaining issue - that there may be no link between recognising a 'bargaining agent' and actually bargaining with that agent - has been widely debated in the 1990 's. This has prompted a public policy interest in the 'bargaining in good faith' notion (Anderson \& Walsh, 1993). ${ }^{3}$ The distinction between recognition and actual bargaining could be argued as being in line with the freedom of choice principle and the overall market orientation of employment relations under the ECA. However, the distinction could open for frequent, organisational based disputes over employee access to collective bargaining (as was the case in Denmark prior to the establishment of the Danish model around the turn of the century) (Due et al, 1994).

With the disappearance of award based minima, statutory minimum conditions have become more important under the ECA. This has had a major negative impact on terms and conditions for people in the so called secondary labour market (Harbridge \& Street, 1995; McLaughlin \& Rasmussen, 1998). Although this can be interpreted as the Act is actually working - terms and conditions are determined by market situations at enterprise level - it has prompted an unintentional outcome: deregulation eliciting public pressure for a statutory response pattern. This can be exemplified by the introduction of a youth minimum wage in 1994, the increased political focus on and subsequent rise in the adult minimum wage in 1996-97, the Government announcement of a legislative codification of trial periods and dismissal procedures in 1998 and finally, the pressure for paid parental leave in 1998.

The ECA's extension of personal grievance entitlements to all employees has increased the protection and bargaining power of employees; particularly those employees on individual employment contracts in the primary labour market. The effects on employment relations have been farreaching in terms of: employer and employee behaviour; 
the implementation of improved human resource management practices; and transaction costs.

The positive effects of the extended personal grievance entitlement have included a greater employee willingness to challenge arbitrary and unfair management decisions. This is important to recognise as the ECA generally has increased employer bargaining power (Armitage \& Dunbar, 1993; Whatman et al, 1994; Dannin, 1997). The possibility of an employee challenge to managerial decisions has been an incentive to implement 'best practice' human resource management procedures (Rasmussen et al, 1996).

There have been, however, several negative effects associated with extended personal grievance entitlements. There has been a significant increase in the number of grievances taken at the Employment Tribunal, currently running at over 5,000 cases a year (Harbridge, 1998). This has prompted employer claims of a growth in litigious behaviour with resulting negative impact on employment and economic efficiency. It has also spurred the Government to announce that it intends to further refine the ECA (Rasmussen \& McIntosh, 1998: 244-5). While litigious behaviour is clearly problematic it must be noted that Hector \& Hobby (1998) found that the majority of grievances were actually resolved informally at workplace level and that the number of tribunal cases constituted less than four cases per thousand employees.

\section{The bargaining scenario in Denmark}

The Danish employment relations system is probably more non-prescriptive than the New Zealand system under the ECA. There is no general legislation - such as the ECA that covers employment relations and particularly bargaining behaviour. Instead there is a heavy reliance on collective agreements which stipulate both the employment relations framework and terms and conditions. There is only the Salaried Employees Act (Funktionarloven) which stipulates basic employment relations entitlements for whitecollar employees and "...in the case of blue-collar workers, basic terms are almost exclusively provided for by collective agreements." (Burgess, 1991b: 25). However, a number of significant terms and conditions - leave, retirement, etc. - are set in statute by various pieces of legislation (see below).

It is a major difference between the two systems that collectively agreed conditions has been prevalent for a long time in Denmark. The voluntaristic Danish system has historically had a strong collective focus. ${ }^{4}$ Instead of legislation, the Danish model is built around two General Agreements and a plethora of collective agreements specifying terms and conditions in particular industries or occupations. This arrangement has been in place since the so called 1899 'September Compromise' although further extensions and refinements have been on-going to the present day (Scheuer, 1992; Due et al, 1994).

"The General Agreement (Hovedaftalen) regulates each party's rights of organization and association, the recognition of managerial prerogatives, the status of col- lective agreements, unfair dismissal, and enabling provisions - to be fleshed out by industry agreements - on shop stewards. The Co-operation Agreement (Samarbejdsaftalen) /...../ establishes a framework for industrial co-operation, information and consultation on a wide range of issues." (Burgess 1991a: 25).

Employee 'voice' or representation is an example of the predominance of collective agreements. There are four main channels for employee representation - shop stewards, cooperation committees, employee board directors and health \& safety committees. Of these, the first two channels are the most important ones and they are founded on collective agreements (Knudsen, 1995). While employee board directors and the health and safety committee have important roles they are less significant in terms of day-to-day employment relations and in terms of issues dealt with. Additionally, legislation regarding employee board directors and health and safety committees were introduced subsequent to tripartite negotiations.

The approach surrounding legislation regarding employee board directors is typical for development of employment relations legislation in Denmark. The need for legislation and the main issues are first established between employers' organisations and the unions and then legislation and implementation issues are dealt with in tripartite negotiations. While there have been deviations from this pattern (see below), it is still true by the end of the 1990's that "Denmark still has a system with strong corporatist traits." (Scheuer, 1992: 193).

The Danish membership of the European Union is increasingly challenging the voluntarism of the Danish system as the national implementation of EU-directives is supposed to ensure that the entire labour market is covered by the regulations. While most employees are covered by collective agreements this is not the case for everybody. Thus, the implementation of the directives through collective agreements - as preferred by the trade unions, the employers' organisations and the state - seems to be inadequate and legislation more appropriate. This will threaten, however, the voluntarism of the 'Danish model' (Knudsen \& Lind, 1999).

Another interesting example of the impact of European standardisation, is the issue of 'closed shop' arrangements. In principle, it is possible to implement 'closed shop' arrangements in the private sector. And there have been several hotly disputed examples over the years. It is, nevertheless, not a major issue because of two limiting factors. Following a 1981 decision in the European Court of Human Rights, the Danish Parliament legislated that "an employer may not dismiss an employee for not being a union member unless the employee knew that union membership was a condition of employment." (Burgess, 1991a: 33). Secondly, collective arrangements have also had an impact in this area since the Employers Federation (DA) prohibits its member companies from entering into closed shop agreements and this sets the trend for the rest of the private sector labour market. 
Although voluntarism is a cornerstone in the regulation of industrial relations in Denmark, the principle of 'free collective bargaining' is frequently violated since the relationship between the state and free collective bargaining is in reality very flexible. During the 1970 's, direct state intervention in collective bargaining took place in three out of the five national bargaining rounds $(1975,1977,1979)$ because the government was faced with a major conflict when the bargaining parties could not agree (Rasmussen, 1987). This happened also in 1985 and 1998, but since the 1970's various governments have typically intervened by regulating single elements in the agreements (in 1981, 1983 and 1991). Governments have influenced the agreements 'indirectly' by 'recommending' a general level of wage increases followed by an implicit or explicit threat that higher levels would be punished by higher taxes. Finally, governments have used public sector bargaining to set a level for subsequent bargaining in the private sector (1991 and 1997).

While it is beyond the scope of this article, it is important to have an in-depth understanding of the above discussed interaction between the labour market organisations and the state since it provides the Danish system with a lot of flexibility, economic efficiency and socially balanced outcomes. It also makes the system rather contradictory with a very large role for the state in a system that is basically voluntaristic and with strong collective action at both national, industry and workplace level.

The sanctity of contract principle has been a key element of Danish employment relations since the 1899 'September Compromise'. This was further buttressed by the introduction of the distinction of disputes of interest and disputes of rights in 1908. This has provided for a strong role for the pre-dominantly bi-partite Labour Court in implementing these principles. There is strong support from both employers and unions for these principles. The employers' organisations regard this as not just a way of limiting industrial disputes during the collective contract period but also as a way of avoiding individual employers being picked off by the unions. The unions consider this system as a cornerstone for creating a relationship based upon mutual trust between the unions and the employers which provides for incremental reforms and improvements. Thus, the principles have been fine-tuned and further strengthened over the years. For example, the sanctity of contract principle has recently been strengthened by legislation in 1993 requiring individual employment contracts to be in writing (Scheuer, 1996: 194).

When it comes to recognition and bargaining, there exists no legislative requirement regarding recognition of 'bargaining agents' and ('good faith') bargaining. Union activities are protected by the freedom of association right in the Constitution. However, this is a general protection of the right to form associations (be it a bridge club or a political party) and it provides no particular protection for union activities. Thus, recognition and bargaining are ultimately reliant on market strength in order to force the other side to the bargaining table. This will not be the case with organisations covered by the General Agreement
(Hovedaftalen) as these organisations have already agreed to recognition and bargaining. However, employers outside the employers' organisations can resist both recognition and bargaining. And this can lead to protracted industrial disputes. For example, a long-term conflict involved restaurants in historical Nyhavn, Copenhagen during 1996 and 1997 (Waddington et al, 1997)

As stated above, legislation is important in areas of minimum conditions. This includes: holiday entitlements (Holidays Act), parental leave entitlements - including paid leave (Maternity Leave Act), additional retirement payments (ATP Act), and sick leave entitlements (Daily Sickness Benefit Act). Many of these entitlements are further enhanced through collective agreements. This is similar to the preECA situation in New Zealand. It is noticeable, however, that there is no Danish statutory minimum wage. A statutory minima ('garantiløn') was introduced as part of the 1977 incomes policy intervention but this temporary measure to protect low paid workers disappeared again subsequent to the 1981 collective bargaining round.

The redundancy protection is also weaker in the Danish system. Neither countries have any significant statutory requirement to pay redundancy - though it has recently been a topic of changing legal precedent in New Zealand (Rasmussen \& Lamm, 1999) and Danish white-collar workers are entitled to a maximum of 3 months salary after 18 years of employment (Burgess, 1991b). The redundancy concept is virtually unknown in Danish employment relations. Instead there are limited notice period requirements for white-collar workers according to legislation (up to 6 months salary after 9 years of employment) and for bluecollar workers according to collective agreements (up to 4 months salary)

Some would say that the generous unemployment benefit system in Denmark is a de facto and permanent redundancy payment system ( 90 per cent of former wages, with a maximum of DKr 538 - around NZ\$150 - per day). It certainly reduces opposition against redundancy among many low paid employees if they can get 90 per cent of their former wages in unemployment benefits (assuming they are not faced with long-term unemployment). This tends to create a labour market with a high level of numerical flexibility amongst low paid employees.

When it comes to working time regulations, New Zealand is clearly more deregulated than Denmark. Statutory restrictions on working hours are nearly non-existent in New Zealand, except for a general protection on grounds of health and safety stipulated by the Health and Safety in Employment Act 1992. In Denmark, there is an 11 hour break period prescribed by statute and European Union regulations may also impinge on working time regulations in the future. Both countries have specific regulations in areas such as transport. Collective agreements will stipulate working time limits for most Danish employees covered by these agreements. This means that Danish employees are also in this area more subject to collective regulation than their colleagues in New Zealand. 
In terms of personal grievances, the Danish situation is very similar to the pre-ECA situation. If a collective agreement exists and the union believes that it is not respected by the employer (pay and other working conditions are lower than prescribed in the agreement), then the union can act on behalf of the member and take the case to the Labour Court if need be. However, if it cannot be related to a collective agreement - which means that this sort of work is not covered by a collective agreement - the union can take industrial action in order to force the employer to sign a collective agreement. In the case that no collective agreement exists and the employee believes that the employer violates the individual contract, then the employee or his/her union can go to the common law courts. These courts have often decided - in case the individual contract is unclear - that the employer has to respect some sort of average norm for working conditions (standards often set in a collective agreement covering similar types of work as that of the complainant).

\section{Unions: role, trends \& issues}

The development of union membership in the 1990's constitute one of the sharpest differences between the two countries (see Figure 1 and Appendix 1). Under the ECA, the unions have lost nearly half of their members and union density has dropped from 44.9 percent in 1989 to under 19.2 percent in 1997. By contrast, the Danish unions have maintained their high level of union density; increasing from 78 percent in 1990 to 83 percent in 1997. The Danish unions have increased their membership and overall union density on the background of a growing workforce in the 1990's.

When the similarities in bargaining principles in Table 1 are considered, this contrasting experience could be a surprise. There are, however, obvious reasons for expecting some divergence, though maybe not such a large degree of

\section{Figure 1. Union density (\%), Denmark and New Zealand}

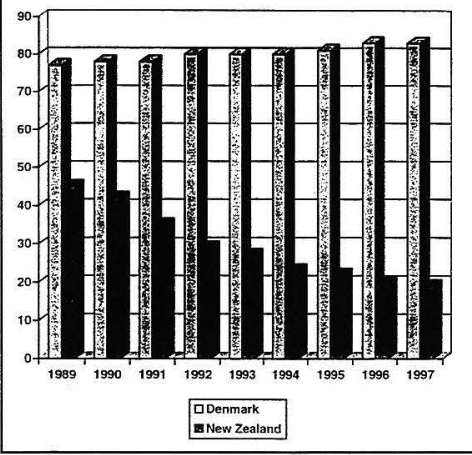

divergence. The discussion of the bargaining principles showed that there is an inherent support for collective action in the Danish model while the New Zealand model has no such support and even some manifest obstacles to collective action. This difference regarding collective action will be further discussed in the following.

In his seminal comparative article of union trends, Visser (1981) suggests four general factors to facilitate a high level of union membership:

(1) industry-wide, multi-employer bargaining

(2) non-contested workplace presence

(3) inclusive bargaining (eg. new employees)

(4) overcoming the 'free-loader' problem

Visser's factors are of interest as they have been used by Harbridge \& Honeybone (1995) to evaluate the status of unions under the ECA. ${ }^{5}$ Their detailed analysis of the decline of unionism in the 1990's (1995: 236-246) presents little hope for a reversal of the fall in union density in New Zealand.

"The ECA works against all four of Visser's conditions for successful unionism. Barriers to multi-employer bargaining, failure to provide for non-contested status as unions, failure to allow automatic inclusive bargaining, and failure to allow for any 'closed shop' arrangements, necessarily predicate against any reversal of union decline in New Zealand."

(Harbridge \& Honeybone, 1995: 246).

On that background, it is interesting to see how the same four factors can explain the continuously high union density in Denmark.

The Danish unions have succeeded in developing industry-wide, multi-employer bargaining. This is manifested in the General Agreement (Hovedaftalen) but it is also supported by three other factors. First, recent changes amongst employers' organisations and unions have emphasised industry bargaining. So called 'cartel bargaining' means that national industry bargaining will often involve a group - a cartel - of unions and this tends to reduce inter-union conflict (Scheuer, 1992; Lind, 1999). Second, industry-wide, multi-employer bargaining is closely related to enterprise bargaining. While industry bargaining sets the parameters for enterprise bargaining, it is the strength at workplace level that ultimately underpins union demands at industry level. Increases in terms and conditions obtained at enterprise level will also subsequently feed back into industry negotiations. ${ }^{6}$ Third, there is significant support for industry bargaining amongst employers since it tends to reduce transaction costs by setting general parameters for enterprise bargaining. It also reduces inter-employer competition in a labour market characterised by low unemployment and strong unions.

The ability of the Danish unions to obtain a non-contested institutionalised workplace presence is based, as mentioned 
above, on the unions' historical agreement with the employers' organisations (Due et al, 1994; Scheuer, 1992). The containment of inter-union disputes is, as with industry-wide bargaining, vital to avoid damaging disagreements at workplace level (instead disagreements are solved by the help of the appropriate union federation). The unions' emphasis on employee voice or industrial democracy have further secured them workplace presence. This is opposite to the more direct bargaining approach taken by New Zealand unions (Rasmussen, 1997). Finally, the union role is wider (see below) and the union behaviour has traditionally been moderate. Thus, the negative public attitude, wellknown in New Zealand, associated with 'bloody-minded' unionism and inconvenient strike activity is less prevalent.

In a situation where the vast majority of employees are union members, the issue of 'inclusive bargaining' (negotiating for members and non-members alike) - becomes less important. As the union is normally party to the collective employment contract, the terms and conditions tend to become general standards. Thus, the collective contracts will cover particular types of jobs rather than particular individual employees. ${ }^{7}$ Collective agreements also provide nonunionised employees with the same working conditions if they work for an employer who has signed a collective agreement covering the kind of work these employees are doing. The Danish unions have also secured through the unemployment insurance system that the unemployed can continue their union membership which avoids the exclusiveness of the unemployed found in several other countries. Finally, the unions have constantly tried to overcome the traditional differences - gender, occupation and sector amongst union members (Scheuer, 1992: 178). Although the 'solidary wage policy' has become less pronounced amongst unions in the 1990's (Lind, 1996), a widening of differentials has been avoided.

While the 'inclusiveness' issue is less important in bargaining or for union strategies the same cannot be said for the latent propensity to 'free-load'. In a situation with high union density an obvious question is why should employees pay union membership if they can get many of the benefits accrued by collective bargaining for free? Free-loading can be rather damaging for union strength since it could undermine the three other above mentioned factors underpinning multi-employer bargaining. Besides securing support for collective action amongst employees and employers, Danish unions have relied on three other 'levers': involvement in training and education, membership services, and involvement in the unemployment insurance system.

"Thus union-controlled unemployment insurance funds in Denmark, Sweden, Belgium and elsewhere are seen as contributing to high union density, as is the role of Danish unions in enforcing individual employment rights through the labour courts."

(Ferner \& Hyman, 1992: xxiii).

The link between high levels of union membership rates in Denmark, Sweden and Finland and the system of unemployment insurance is worth exploring. In these countries the so-called Gent-system is applied, which means that unemployment insurance is voluntary and based on membership of unemployment funds. Thus, an employee can be a member of an unemployment fund without being a member of a trade union. However, the unemployment funds have traditionally had - and in most cases still have a very close relationships with the unions. In Denmark, this is particularly so amongst the trade unions affiliated to the LO union federation. Formally the unions cannot combine membership of an unemployment fund to trade union membership, but in reality they often act as if it involves the same organisation. In fact, many members are not aware of the distinction: in order to become a member of an unemployment fund they join a trade union, and several surveys have found that this constitutes one of the main reasons why employees take up union membership (Lind, 1996).

Most Danish trade unions will also have a substantial 'professional' role through their involvement in training and education. Traditionally, this has been strong amongst trades people and semi-skilled groups. However, it now extends across the whole range of trade unions and has been further embedded by the growth of white-collar and professional union membership since the 1970's. Training programmes are often developed in unison with the relevant employer organisations and training and education have been a key element in reducing unemployment in the 1980's and 1990's. A particular training effort has been directed at shop stewards and employee representatives involved with co-operation committees and company boards. These training activities have generally lifted the unions' profile and it has generated numerous well educated and business-wise trade union activists.

While the 'inclusiveness' mentioned above limits the distinction between unionised and non-unionised employees, union membership still confers many important benefits. As Ferner and Hyman (1992: xxiii) point out, enforcing individual employment rights through the labour courts is an important union service. Union membership provides an element of security - an 'insurance option' - which many employees find of crucial value (Scheuer, 1996). At the same time, there is a range of more customer-orientated services (cheap insurances, rebates, cultural activities, etc.) available, depending on the union involved. These benefits make union membership more attractive though the 'insurance option', training programmes and traditional affiliation tend to be more important when employees have to decide whether to keep or take up union membership.

\section{Conclusion}

While the statutory minimum code and legal decision-making in the employment institutions still have a strong presence, the Employment Contracts Act has constituted a sharp break with the historical pattern of New Zealand employment relations. A more voluntaristic system with an individualistic focus has developed in the 1990's. The individualistic focus is associated with a particular understanding of the freedom of association principle (more like a 
'freedom of disassociation') (Dannin, 1997), explicit restrictions on collective action and a growing employer preference for individual employment contracts.

Danish employment relations have followed a more evolutionary pattern which has kept intact a voluntaristic system with a collective focus. The strong position of collective arrangements is a form of de facto regulation which makes legislative arrangements less necessary. At the same time, the bipartite collaboration between employers and unions continues to be linked to tripartite, corporatist policy development in a way which supports long-term stability and a flexible development of Danish employment relations. Focussing on the co-operative pattern of employment relations, one could argue that the Danish system of labour market regulation is based upon an ongoing and tacit social pact between state, capital and labour which secures a 'responsible' and communicative behaviour amongst the so called 'social partners'.

It has been argued that the two employment relations systems have converged in the 1990's with the New Zealand system becoming more voluntaristic and with the Danish system having a few more statutory entitlements. The two countries' employment relations systems are based on voluntaristic bargaining arrangements with a significant role for state imposed regulations in the area of contractual disputes and statutory minima. However, within this predominantly voluntaristic system an overall divergence between an individualistic and a collective focus has become more pronounced. This has been particularly prevalent in areas such as personal grievances, employee 'voice', vocational training and public policy involvement. The trends in union membership in the two countries present a clear illustration of such divergence.

Finally, it has been indicated that in order to understand the patterns of convergence and divergence, it is necessary to work with more detailed and subtle analyses which take into account that the wider historical and political context is often more important than the formalised, statutory framework. Employment relations are embedded in the economic, social and political institutions and the social relations of the society.

\section{Future research}

There is a need to further pinpoint the important similarities and differences between the two employment relations systems. In particular, it is of interest to conduct more evaluative research regarding workplace impacts of these similarities and differences. For example, what are the impacts on workplace employment relations of a high degree (or absence) of collectivism and employee influence?

The emphasis above on both the employment relations system and the contextual factors could be developed further. Do employment relations systems have significant employment, productivity and flexibility effects (as initially suggested by the proponents of the Employment Contracts Act) or is the interaction with and support of contextual factors
- for example, training and education systems - of greater importance?

\section{Notes}

1 For language reasons, we have tried to restrict references to the Danish system to references written in English.

2 Although lack of awareness of contract status still exists amongst some employees (Rasmussen, 1996: Hector \& Hobby, 1998)

3 As known from Canadian employment relations (Clark, 1993: 161).

4 Typically, the sub-title of the book on the Danish model by Due et al 1994 refers to the Danish system of collective bargaining - see references.

There has been an important shift towards industry level bargaining - what Danish commentators call 'decentralisation' - in the 1980's and 1990's and this has provided the Danish system with new flexibility, new organisational patterns and new problems (eg. Scheuer, 1992; Lind, 1999). Discussing this shift is, however, beyond this article.

5 See Harbridge \& Honeybone (1995: 236) for a succinct presentation of Visser's four factors.

6 For sake of simplicity, we here 'overlook' complications caused by the traditional occupational basis of many union and instances of insufficient workplace presence (eg. Scheuer, 1996). We will discuss these complications in a later comparative article since they have had an important impact on New Zealand unionism.

7 This difference is of major importance, as stressed by Dannin (1997: 304) in her criticism of the ECA.

\section{References}

Anderson, G. (1997) Interpreting the Employment Contracts Act: Are the Courts Undermining the Act?' California Western International Law Joumal, vol. 28 , no. 1, pp. 117-143.

Anderson, G. \& Walsh, P. (1993) Labours New Deal: A Bargaining Framework for a New Century? New Zealand Joumal of Industrial Relations, vol. 18 , no. 2 , pp. 163-176.

Armitage, C. \& Dunbar, R. (1993) Labour market adjustment under the Employment Contracts Act. New Zealand Joumal of Industrial Relations, vol. 18 , no. 1, pp. 94-112.

Boxall, P. (ed.) The Challenge of Human Resource Management, Auckland: Longman Paul.

Boxall, P. \& Haynes, P. (1997) Strategy and trade union effectiveness in a neo-liberal environment. British Journal of Industrial Relations, vol. 35, no. 4 pp. 567-591.

Burgess, Pete (ed.) (1991a) Industrial Relations. European 
Management Guides, London: Incomes Data Services.

Burgess, Pete (ed.) (1991b) Terms \& Conditions of Employment. European Management Guides, London: Incomes Data Services.

Clark, H. (1993) Employment Relations - the New Direction under Labour. New Zealand Joumal of Industrial Relations, vol. 18, no. 2, pp. 153-162.

Crawford, A., Harbridge, R. and Hince, K. (1998) Unions and Union Membership in New Zealand: Annual Review for 1997. New Zealand Journal of Industrial Relations, 23(2), pp. 191-198.

Dannin, E. (1997) Working Free: The Origin and Impact of New Zealand's Employment Contracts Act, Auckland: Auckland University Press.

Due, J., Madsen, J.S. and Jensen, C.S. (1994) The Survival of the Danish Model. A historical sociological analysis of the Danish system of collective bargaining, København: DJØF Publishing.

Ferner, A. and Hyman, R. (eds) (1992) Industrial Relations in the New Europe, Oxford: Basil Blackwell.

Geare, A. (1989) New Directions in New Zealand Labour Legislation. International Labour Review, vol. 128 , no. 2, pp. 213-228.

Harbridge, R. (ed.) (1993) Employment Contracts: New Zealand Experiences, Wellington: Victoria University Press.

Harbridge, R. (1998) Trends in Collective Employment Contracts: 1998. Paper presented at 12th Annual Industrial Relations Conference, Auckland.

Harbridge, R. and Honeybone, A. (1995) Trade Unions under the Employment Contracts Act: will the slimming be fatal? in Boxall, P. (ed): The Challenge of Human Resource Management, Auckland: Longman Paul, pp. 231-249.

Harbridge, R. and Street, M. (1995) Labour Market Adjustment and Women in the Service Industry: A Survey. New Zealand Journal of Industrial Relations, vol. 20, no. 1, pp. 23-34.

Haworth, N. and Hughes, S. (1995) Under Scrutiny; the ECA, the ILO and the NZCTU Complaint 19931995. New Zealand Journal of Industrial Relations, vol. 20, no. 2, pp. 143-161.

Knudsen, H. (1995) Employee Participation in Europe, London, Sage.

Knudsen, H. and Lind, J. (1999) The implementation of EU-directives in national systems - lessons from the Danish case. Transfer, vol. 5, no. 1, pp (forthcoming).

Lind, J. (1996) Trade Unions: Social movement or welfare apparatus?, in Leisink, P. et al: The Challenges to Trade Unions in Europe: Innovation or Adaptation, Cheltenham: Edward Elgar, pp. 105-120.

Lind, J. (1998) Liberalisering på arbejdsmarkedet i New Zealand og konsekvenserne for fagforeningerne. LEO-serien, no. 18, maj 1998.

Lind, J. (1999) Still the Century of Trade Unionism!, in Hoffmann, R., Waddington, J. (eds.): Trade Unions in Europe facing Challenges, Brussels, pp. (forthcoming).

Novitz, T. (1996) New Zealand Industrial Relations and the International Labour Organisation: Resolving Contradictions Implicit in Freedom of Association. New Zealand Journal of Industrial Relations, vol. 21, no. 2, pp. 119-139.

\section{Appendix 1. Union membership, Denmark \& New Zealand}

\begin{tabular}{|c|c|c|c|c|c|c|c|c|c|c|}
\hline \multicolumn{4}{|c|}{ Union membership, Denmark } & \multicolumn{5}{|c|}{ (in 000s, except density figures) } & \multirow[b]{2}{*}{1996} & \multirow[b]{2}{*}{1997} \\
\hline & 1988 & 1989 & 1990 & 1991 & 1992 & 1993 & 1994 & 1995 & & \\
\hline Workforce & 2,627 & 2,634 & 2,629 & 2,638 & 2,636 & 2,641 & 2,647 & 2,648 & 2,629 & 2,621 \\
\hline LO membership & 1,421 & 1,413 & 1,423 & 1,441 & 1,446 & 1,471 & 1,510 & 1,510 & 1,502 & 1,496 \\
\hline FTF membership & 318 & 320 & 325 & 328 & 339 & 338 & 332 & 332 & 338 & 342 \\
\hline AC membership & 99 & 101 & 103 & 106 & 113 & 117 & 128 & 132 & 137 & 141 \\
\hline Outside LO, FTF \& AC & 187 & 194 & 201 & 189 & 199 & 198 & 187 & 189 & 192 & 193 \\
\hline Total union membership & 2,025 & 2,028 & 2,052 & 2,064 & 2,097 & 2,124 & 2,156 & 2,163 & 2,169 & 2,172 \\
\hline Union density (\%) & 77 & 77 & 78 & 78 & 80 & 80 & 80 & 81 & 83 & 83 \\
\hline
\end{tabular}

Source: Danmark Statistik, Tiaars Oversigt

Union membership, New Zealand

\begin{tabular}{lrrrrrrrrrr}
\hline & Dec-85 & Sep-89 & May-91 & Dec-91 & Dec-92 & Dec-93 & Dec-94 & Dec-95 & Dec-96 & Dec-97 \\
Number of Unions & 259 & 112 & 80 & 66 & 58 & 67 & 82 & 82 & 83 & 80 \\
Union membership & 683,006 & 648,825 & 603,118 & 514,325 & 428,160 & 409,112 & 375,906 & 362,200 & 338,967 & 327,800 \\
Density (\%) & 43.5 & 44.7 & 41.5 & 35.4 & 28.8 & 26.8 & 23.4 & 21.7 & 19.9 & 19.2 \\
\hline
\end{tabular}

Source: Crawford, Harbridge \& Hince 1998: 194. 
Rasmussen, E. (1987) Indkomstpolitik i retrospect. Politica, vol. 19, no. 2, pp. 148-161.

Rasmussen, E. et al (1996) Industrial Relations and Labour Market Reforms in New Zealand. in Pacific Economic Cooperation Council (PECC): Human Resources Development Outlook 1995-1996. Monash University, pp 147-171, 1996.

Rasmussen, E. and Deeks, J. (1997) Contested Outcomes: Assessing the Impacts of the Employment Contracts Act. California Western International Law Journal, Vol. 28, No. 1, pp. 275-296.

Rasmussen, E. and Lamm, F. (1999) An Introduction to Employment Relations in New Zealand, Auckland: Longman Paul.

Rasmussen, E. \& McIntosh, I. (1998) Chronicle. New Zealand Joumal of Industrial Relations, vol. 23, no. 2, pp. 237-247.

Scheuer, S. (1992) Denmark: Return to decentralization. Ferner, A. \& Richard Hyman, R. (eds) 1992: Industrial Relations in the New Europe, Oxford: Basil Blackwell, pp. 168-197.

Scheuer, S. (1996) Falles aftale eller egen kontrakt $i$ arbejdslivet, København: Nyt fra Samfundsvidenskaberne.

Visser, J. (1991) Trends in trade union membership. OECD Employment Outlook, Paris: OECD, pp. 97-134.

Waddington, J., Hoffmann, R. and Lind, J. (1997) European trade unionism in transition?, Transfer, vol. 3, no. 3, pp.464-497

Whatman, R., Armitage, C. and Dunbar, R. (1994) Labour Market Adjustment under the Employment Contracts Act. New Zealand Journal of Industrial Relations, vol. 19, no. 1, 1994.

\author{
Authors \\ Erling Rasmussen is a Senior Lecturer at the \\ Department of Management \& Employment Relations, \\ University of Auckland, \\ Private Bag 92019, Auckland. \\ E-mail: e.rasmussen@auckland.ac.nz \\ Jens Lind is a Senior Lecturer at the \\ Department of Social Studies and Organisation, \\ University of Aalborg, \\ Denmark.
}

